\title{
Dehumanization, Racial Minority and Female Leadership: An Analysis of Global Trends
}

\author{
Simon Raymond ${ }^{1,2}$ \\ ${ }^{1}$ Melbourne University, Melbourne, Australia \\ ${ }^{2}$ Fullagar Chambers (Law), Brisbane, Australia \\ Email: simonraymondcontact@gmail.com
}

Received 27 June 2016; accepted 16 August 2016; published 19 August 2016

Copyright (C) 2016 by author and Scientific Research Publishing Inc.

This work is licensed under the Creative Commons Attribution International License (CC BY).

http://creativecommons.org/licenses/by/4.0/

(c) (i) Open Access

\begin{abstract}
Purpose: The use of dehumanization, directed toward racial minorities, impresses as a global trend of significance, spanning from broad generalisations with regards to black community members holding a lower status through to Russian politicians terming Barack Obama and Michelle Obama as mammalian apes (or, monkeys). This report analyses the use of dehumanization and the validity of racial degradation. Female leadership is also analysed. Methods: A comparative analysis was performed assessing the achievements of African Americans in comparison with white (including caucasian) society, with a gender comparison to assess for consistency across genders. The categorisation of racial minorities based on the satisfying of criteria for conscious being recognition was also considered. Results: African Americans have held positions, and achieved success, equally respectable with that of the white (including caucasian) community. These members of society also satisfy the criteria for conscious beings. There appears to be no validity to support black or Asian people as representative of a being less than that of a human being. Conclusion: There appears to be no validity behind categorisation of certain races as lesser members of society. Furthermore, there appears no validity behind the use of dehumanization.
\end{abstract}

\section{Keywords}

Conscious Being, Dehumanization, Female Leadership, Racial Segregation

\section{Introduction}

African American History Month (USA; February 2016) has recently concluded, providing impetus in reflection 
with respect to the accomplishments of African American citizens of USA. Another key topic of importance around the world in contemporary times revolves around the use of dehumanization and segmentation. Female leadership also remains a topic of interest in the current global climate.

The re-consideration of previous global discussions in respect of black people perhaps being more comparable to the mammalian ape (or, monkey) as opposed to human beings has been significant, spanning from broad generalisations with regards to black community members holding a lower status through to Russian politicians terming Barack Obama and Michelle Obama as mammalian apes (or, monkeys) (Klikushin, 2016; Greene, 2016; Hund, 2016; Goff, 2008).

This report presents an analysis of the above three key topics of importance through: Comparative analysis of Condoleezza Rice against an appropriate reference being that of namely president Barack Obama; The observed trend in respect of the use of dehumanization globally; Female leadership; and, the interaction of the present topics of interest with relation to global progression.

\section{Data and Methodology}

A comparative analysis was performed assessing the achievements of African Americans in comparison with white (including caucasian) society, with a gender comparison to assess for consistency across genders. A focused analysis was performed in respect of two prominent African Americans. Broad based experiential and observational evidence comparison was then performed for analytical validation. The categorisation of racial minorities based on the satisfying of criteria for conscious being recognition was also considered.

Data triangulation was performed, through use of multiple sources of data, in order to increase the validity of the analysis.

Data triangulation is a powerful technique that facilitates validation of performed analyses (qualitative and quantitative) through cross verification from two or more sources of information (data) (Bogdan \& Biklen, 2006).

\section{Results}

\subsection{Comparative and Gender Analyses}

It seems reasonable to suggest that USA is still generally accepted as the leading nation or one of the most prominent leading nations; Or, at a minimum, it would not seem unreasonable for the suggestion to remain espoused at the present. The report therefore commences, in respect of racial disadvantage, with comparative analysis (incorporating gender comparison) of two prominent African Americans.

Condoleezza Rice (1954; Born in Birmingham, Alabama) the daughter of religious minister John Wesley Rice and High School Teacher Angelena Rice, managed to successfully battle through the substantial adversity posed by racism in the then segregated South to ultimately graduate from St Mary's Catholic High School in 1971, aged 16 years (Antonia, 2005; Encyclopaedia WB, 2015). This was followed by successful progression through Bachelor's, Master's and $\mathrm{PhD}$ level tertiary education in areas revolving around political science and international studies (Biography A\&E LLC, 2015).

In 1981, Condoleezza Rice was then appointed as Professor in Political Science by the Prestigious Stanford University (Stanford University STEC, 2015).

Noteworthy is that Condoleezza Rice has also been awarded a number of honorary degrees for demonstration of excellence, too numerous to cite all, including doctor of laws (LL.D) (OPA, 2012).

During her professional career, there have been many achievements by Dr Condoleezza Rice that had never previously been observed:

- Dr Condoleezza Rice became the first woman of any race to serve as provost of Stanford University, in year 1993 (CNN Library, 2015).

- 1993, Condoleezza Rice also became the first African American to serve as provost of Stanford University (Biography A\&E LLC, 2015).

- 1993, Condoleezza Rice was also the youngest ever to serve as provost in the history of Stanford University (CNN Library, 2015).

- Condoleezza Rice was the first African American female to serve as USA National Security Advisor, appointed in 2001 (Antonia, 2005).

- Condoleezza Rice was the first African American female to serve as Secretary of State USA, holding her position for the period spanning 2004 through 2009 (Stanford University SUHI, 2015). 
Condoleezza Rice has on current reports returned to a Professorship with Stanford University. Professor Condoleezza Rice has been distinguished for teaching excellence, receiving some of the highest teaching honors of Stanford University (White House Archives, 2015). She has also received recognition in other areas for assisting those in need (Ferreira, 2015).

The appropriate point of reference (or, gold standard for comparison) would seem reasonable to set as Barack Obama being the first African American (or, Black) president of USA, given that USA president has generally been viewed as perhaps the most prestigious position and achievement. An analysis against this reference comparison is presented below:

During the period that Condoleezza Rice was reportedly active in the political and government arena, it would have been a practical impossibility for her to become president.

Even to the current date of mid 2016 no female has ever been president of USA. It seems generally accepted that Barack Obama received heavy support from celebrities including Oprah Winfrey (who is known to increase popularity of an entity by estimates ranging from two to ten times as great) (Nahon \& Hemsley, 2013; Lange. 2015; Nielsen (media and entertainment) Company, 2015), rapper "Wil.i.am” (producing video music, which supported Barack Obama for election as president, that reportedly went viral) (Nahon and Hemsley, 2013), in addition to a range of other high-level persons providing significant support, including German-heritage actress and business woman (and 2007 world's sexiest woman), facilitating the solicitation of special pledges of allegiance from USA citizens to Barack Obama (Spiering, 2015; UOV, 2015; Alba Family Crest, 2015; Ertelt, 2015; Daily Mail, 2015; BBC News, 2007; FoxNews, 2015). A very different style of election campaign.

There has been speculation as to Barack Obama identifying as a purported Muslim. This is coupled with an apparent purpose of Islam directed toward apparent "annihilation" of Israel. Whilst outside of the scope of this publication, from the author's view the pledges of allegiance facilitated by German-heritage assistant, could be indicative of a head of church structure similar to that traditionally associated with Germany (although not nazi), a theorized second axis of change (religious) potentially negative with respect to Israel. This is consistent with the recent announcements in British media communications in connection with themes of a German nature, coupled with the overt head of church Monarchial structure. That being said, it would be accepted as reasonable argument that the German-heritage of the USA official is incidental and miscommunication being understandable given the British media communications. There is some argument for caution with respect to Israel, given the common Abrahamic origin of: Islam, Judaism and Christianity. Intentions for directed attack (termed annihilation) at the Israelites may seem harsh when there are three different religions all streaming from the same common origin of a historical figure, namely Abraham-the ancestor of the Israelites. It seems harsh to direct attack based on incorrect choice of the religious stream (Judaism, Islam, Christianity) from the common Abrahamic origin. USA being the country of liberty would seem potentially well-positioned to consider continuing to protect the religious choice of the Israelites, based on the inherent identity of USA as a protector of freedom, regardless of disagreement from certain factions of society with respect to the appropriateness of the Abrahamic stream Israelites most identify with.

It seems plausible that the above deviations from normality could be explained by perceived external threats, global instability and uncertainty causing implementation of the above for perceived purposes of self-defence.

For the purposes of the current report, focused analysis on the strategic moves of governments is outside the intended scope, and the principle point regarding the above is, in general, to underscore the severe global climate, uncertainty and instability faced by president Barack Obama during his term, as it should be rightly taken into account in considering the validity of the apparent heavy criticism directed toward his presidency. As demonstrated above, Barack Obama has faced an apparent period of substantial religious and culture complexity which likely permeates and effects the rational paradigm strategy. In fact, such instability and related factors may contribute toward an explanation in respect of the current trends for dehumanization and racial degradation that impress as key forces driving change in the current global culture.

On the positive perspective, Barack Obama (USA president 2009-2016) held one of the most prestigious recognised world leadership positions. He demonstrated that any race or persons, including black persons, can achieve success at the highest level, equivalent to that of the caucasian community. On the alternative perspective, a range of sources in USA and overseas reported Barack Obama as either "the worst president since WII" or "the worst president ever," based on broad polls in addition to views of specific. Reports even suggested that the African American community came off worst (Boyer \& Dinan, 2015; Curl, 2015; Tracinski, 2015; Chambers, 2012). 
Barack Obama even being termed "a fraud and a common and constitutional criminal (Elder, 2015; Wright, 2015; Lindorff, 2015; Threshold Divisions, 2014; Shapiro, 2014; The Political Insider, 2015).” With that said, the severe circumstances faced by Barack Obama during his presidency should also be taken into account. If he genuinely was a professor of law (or, respected person in general) on entering the presidency, then going from that to a person viewed as essentially nothing more than a serious criminal and fraud does not seem fair, and in fact could well be devastating, if such imputations are based on incomplete grounds which do not take into account the full severity of the difficulties faced during his presidency. Noteworthy is that caucasian USA presidents have also had similar criticisms in the past, for instance allegations of a serious nature accompanied by requests for impeachment. In fact, it seems generally accepted that politicians have a tendency to polarise the community.

Initial impressions following from the focused analysis, involving Condoleezza Rice and Barack Obama, suggest that African Americans contain the potential to achieve at the same level as caucasians and that this is consistent across gender. This is supported by broad based observational and experiential evidence of broad based success in the African American community, spanning politicians (Example: Colin Powell) through athletes (Example: Serena and Venus Williams) through artistic performers (Example: Onika Maraj).

In summary, the comparative analysis indicated: (A) African Americans to contain the potential to achieve at the same level as caucasians and that this is consistent across gender; (B) that the findings from the focused analysis are supported and consolidated by experiential and observational evidence that demonstrates broad based success in the African American community, spanning professional and political success through athletes and artistic performers of the highest level.

\subsection{Dehumanization: A Current Global Trend}

Powered by drivers including global instability, an increasing trend for targeting specific groups around the globe with strategic dehumanization strategies is becoming evident. Russian politicians have appeared to detriment the power and prestige of the USA government by terming, in media communications, Barack Obama and Michelle Obama as mammalian apes (or, monkeys) (Klikushin, 2016; Greene, 2016). Kim Jong Un has made similar comments (Capehart, 2016). In addition to these specific political communications, broad based opinion expressed in research literature supports a view that perhaps black people are more comparable to the mammalian ape (or, monkey) than to human beings (Hund, 2016; Goff, 2008).

That being said, USA has also launched attacks and there is suggestion that the use of the name Barack Hussein Obama was a strategic (designed name) direct dehumanization attack at the Middle-East, although there is opposing argument, specifically that the name was designed for the purposes of identifying with the Middle-East, with genuine altruistic intentions, given the ongoing perception of a lack of interest in the culture of the given area by USA (Waismel-Manor \& Stroud, 2012).

The trend for dehumanization is concerning and indicates a significant move backward. In line with this, there have been performed analyses indicating a predicted possibility revolving around black people going back to slavery, and perhaps black survival being untenable (Rabinovitz, 2016; Hund, 2016; Goff, 2008; Hussein, 1985).

Earlier this year USA announced that anti-slavery activist Harriet-Tubman had been placed on the US \$20 bill, amidst the surrounding circumstances.

There has been research to indicate that even in formal testing some caucasians still view black people as a lower category of being (Szeming, 1941-1945; Rabinovitz, 2016). Both black people and asians have suffered this problem throughout history (Szeming, 1941-1945; Rabinovitz, 2016). There has been talk of countries considering the re-introduction of legislation enforcing official racial segregation, which is associated with obvious degradation.

It would seem reasonable to explore whether further protective measures could be undertaken, including extended judicial court rulings prohibiting society from officially declaring certain races to be less than humans, in addition to exploring any further benefit that could be achieved through international treaties and conventions.

\subsection{Further Scientific Considerations: Anthropology, Anatomy, Biology and Consciousness}

A very basic criteria, based on foundations including anthropology and anatomy, for satisfying classification as a human being was traditionally thought to be the presence of opposable thumbs. Even if the person possesses significant mental impairment then this should have no impact with respect to whether they are viewed as human 
beings given there are many caucasians around the globe with disorders of significant to substantial impairment and disadvantage (examples being genetic disorders including down's syndrome and fragile x syndrome). Based on this, there appears no reason to suspect black or Asian people as representative of a being less than that of a human being.

That being said, contemporary perspectives may be argued to revolve around more modern classification focused on the consciousness (or, conscious level) of the being, with indicators (or, key criteria) for conscious being recognition including: 1) ability to make decisions that achieve a positive or strategic benefit; 2) learning; 3 ) survival instincts; and, 4) moral conduct (Raymond, 2016a). Based on such modern criteria, there again appears no reasons to suspect black people, Asians, or any other category of society as representative of a being less than that of a human being (Raymond, 2016a).

The above finding is supported by both the present focused analysis in addition to broad based experiential and observational evidence including the multitude of notable successful African Americans who have satisfied relevant factors with high level success, spanning politics through athletes through artistic performers

\subsection{Female Leadership}

USA appears to be lagging the rest of the world in acknowledging females as having the capability to be the top level leaders and achievers. For instance, USA has never had a female president yet a wide range of countries spanning Canada (female prime minister) through Philippines (female president) have had a female in the top leadership position. Whilst the female prime minister of Australia received noted criticism, there have been male prime ministers in Australia receive just as much criticism and be removed from office early before their intended period of service due to poor performance.

Having said the above, it could possibly be argued that having African American females achieve success in high-level positions despite having to overcome both racial and female disadvantages indicates that USA does in fact engage genuine effort directed at equality for all citizens.

The important point in specific is the increasing threat to women globally, with the development of increasingly complex forms of abuse including the misuse of psychiatry (and psychology). Essentially, this may involve the abuser expressing concerns about the mental health or welfare of the woman (victim), apparently unbeknown to doctors (and other personnel) who were under the impression that the abuser was trying to help the woman in question, with the abuser subsequently assuming increasing control over the woman including her finances based on her fraudulent mental health or welfare issues (NHFW, 2016; Raymond, 2016b; Shin, 2016). There also purportedly exists, in theory, more complex forms of abuse possibly increasing in development that involves intelligent strategic abuse often termed broadly as "mind coding" which commonly involves subjection of the victim to abuse in conjunction with brainwashing type techniques (Raymond, 2016b).

Female leadership and women's rights further remain an area for specific protection given the increasingly complex abuse developing in relation to the gender, including control of finances, mind slavery and other associated areas (NHFW, 2016; Raymond, 2016b).

\section{Discussion}

\subsection{General Discussion}

In brief, the analysis revealed that Condoleezza Rice: came from a disadvantaged up-bringing to battle through racial discrimination and segregation; achieved high-level tertiary education including $\mathrm{PhD}$; is a Professor of the prestigious Stanford University; became the first African American female to achieve a number of positions including Secretary of State USA, National Security Advisor (NSA) USA, and provost of Stanford University; has received some of the highest honors awarded in teaching excellence; has been awarded a number of honorary degrees; has received recognition for contributing to those in need.

Through achieving the above, Condoleezza Rice has demonstrated to the African American community (and other black communities around the world) that it is possible to break free from the oppression that is complained of and make achievements to the level of professor at a prestigious university, be appointed as a senior USA government official, and contribute to society in a manner that is just as intelligent, powerful and influential as any white American. Through demonstrating this, the contribution of Professor Condoleezza Rice, if society is willing to observe, is very significant.

It is noted, in regards to Condoleezza Rice, that during her period as NSA the terrorist attack involving World 
Trade Centre occurred and this could be argued against her success. That being said, it should be remembered that she was one member of a large government organization (administration) led by George W. Bush and it would seem unfair to direct all blame toward her. In addition, it would seem reasonable to argue that measures from the previous advisory personnel leading up to her term as NSA could have been lacking in given areas.

There is reasonable argument that Barack Obama was the appropriate reference point for comparison.

The position of USA president is generally accepted as more prestigious than that of secretary of state. It therefore seems reasonable to view the achievements of Barack Obama (USA president, 2008-2016) as being equally respectable in comparison to Condoleezza Rice.

The finding that black community members contain the potential to achieve at a level comparable to caucasian society is supported and consolidated by experiential and observational evidence that underscores broad based success in the African American community, spanning politics through artistic performers, as detailed above.

Racial minorities including African Americans also satisfy the criteria for recognition as equivalent beings to that of white (including caucasian) society based on historic classification methods and also modern categorisation methods that focus on the level of consciousness demonstrated by the being.

The analysis therefore revealed the lack of any credible argument to validate any suspicion that black people, asians, or any other category of society may be representative of a being less than that of a human being.

The analysis revealed that female leadership and women’s rights remain important global topics.

\subsection{The Analysis and Validity of Findings}

The credentials of the author (researcher), inclusive of areas with focus directed at statistical, qualitative and quantitative analysis, are detailed, in brief, in the biographical data section.

The analysis presented in the current report was based on intelligent and planned rationale. The analysis performed incorporated analytical techniques revolving around data triangulation in order to increase validity and reliability regarding the report findings. Further validation and consolidation of the conclusions drawn was facilitated by way of verification (and confirmation of consistency) of the focused analysis through examination of broad based experiential and observational evidence.

Electronic sources were used strategically where possible to increase the likelihood of persons being able to access the citations regardless of their academic standing (abilities).

\subsection{USA and Freedom of Speech}

USA has in recent times been demonstrating strong leadership in the promotion of freedom of speech and expression and in fact USA government officials have even, in recent times, travelled around the world to teach it, and urged leaders of other nations to properly allow and promote freedom of speech and expression (Legal Information Institute Encyclopedia, 2015; Reuters USA, 2015; Bull, 2015; TIME (WORLD), 2016). Therefore, this report will no doubt be keenly received by the global community.

\section{Conclusion}

In conclusion, at this stage there does not appear any credible argument to validate any suspicion that black people, Asians, or any other category of society may be representative of a being less than that of a human being. Female leadership and women's rights present as important areas to direct significant future protection toward.

\section{References}

Alba Family Crest, Coat of Arms and Name History (Jessica Marie Alba DOB: 1981 Listed as Contemporary Notable for German Heritage). https://www.houseofnames.com/alba-family-crest

Antonia, F. (2005). Condi: “The Condoleezza Rice Story”. Suffolk: St Edmundsbury Press, Politico’s.

BBC News (2007). Actress Alba Is “Sexiest Female”. BBC News. http://news.bbc.co.uk/2/hi/entertainment/6593403.stm

Biography Division of A\&E Television Networks LLC (2015). Condoleezza Rice Biography: Government Official. Biography.com. http://www.biography.com/people/condoleezzarice-9456857

Bogdan, R. C., \& Biklen, S. K. (2006). Qualitative Research in Education: An Introduction to Theory and Methods. Allyn \& Bacon. https://en.wikipedia.org/wiki/Special:BookSources/9780205512256 
Boyer, D., \& Dinan, S. (2015). Hands Down, Obama Is the Worst President since WWII: Poll. The Washington Times. http://www.washingtontimes.com/news/2014/jul/2/curl-obama-is-the-worst-president-ever/ http://thefederalist.com/2015/11/19/barack-obama-worst-president-ever/

Bull, A., \& Butler, D. (2015). American Vice President Biden Urges Leaders in the Eastern Area to Allow Free Speech. Reuters. http://www.reuters.com/article/us-usa- biden-idUSTRE7B20EM20111203

Capehart, J. (2016). North Korea’s Racist Rant against “Wicked Black Monkey”. Obama, https://www.washingtonpost.com/blogs/post-partisan/wp/2014/05/08/north-koreas-racist-rant-againstwicked-black-monke y-obama/

Chambers, F. (2012). Obama Rated Worst President since WW2 in Embarrassing Poll. Daily Mail (Australia and UK). http://www.dailymail.co.uk/news/article-2678005/Obama-rated-WORST-presidentWorld-WarIIembarrassing-new-poll.ht ml\&gt

CNN Library (2015). Condoleezza Rice Facts. Cable News Network Turner Broadcasting System Inc. http://edition.cnn.com/2013/07/08/us/condoleezza-rice-fast-facts/

Condoleezza Rice, Secretary of State. White House Archives. http://georgewbush-whitehouse.archives.gov/government/rice-bio.html

Curl, J. (2015). Obama Is the Worst President Ever. The Washington Times. http://www.washingtontimes.com/news/2014/jul/2/curl-obama-is-the-worst-president-ever/

Daily Mail (2015). Jessica Alba Named Sexiest Woman in the World 2007. Daily Mail. http://www.dailymail.co.uk/tvshowbiz/article-450788/Jessica-Alba-named-sexiest-womanworld.html

Elder, L. (2015). Under Obama, Blacks Are Worse Off-Far Worse. Townhall News. http://townhall.com/columnists/larryelder/2015/07/23/under-obama-blacks-are-worse-off--far-worse-n2028985

Encyclopaedia of World Biography (WB) (2015). Condoleezza Rice Biography. http://www.notablebiographies.com/news/Ow-Sh/Rice-Condoleezza.html

Ertelt, S. (2015). Jessica Alba, Natalie Portman Pledge Allegiance to Obama, Abortion. National, Life News. http://www.lifenews.com/2012/09/20/jessica-alba-natalie-portman-pledge-allegiance-to-obamaabortion/

Ferreira, G. (2015). Condoleezza Rice Receives Award for Helping Youth. The Indianapolis Star. http://www.indystar.com/story/news/2015/09/10/former-us-secretary-state-receives-award-helpingyouth/72041024/

FoxNews (2015). Celebrities Rave about Obama Speech. Associated Press. http://www.foxnews.com/story/2008/08/29/celebrities-rave-about-obama-speech.html

Goff, P., Eberhardt, J., Williams, M., \& Jackson, M. (2008). Not Yet Human: Implicit Knowledge, Historical Dehumanization, and Contemporary Consequences. Journal of Personality and Social Psychology, 94, 292-306. http://www-psych.stanford.edu/ mcslab/PublicationPDFs/Not\%20yet\%20human.pdf http://dx.doi.org/10.1037/0022-3514.94.2.292

Greene, S. (2016). There May Be a Lot of Reasons Putin Changed Russia's Syria Policy, but Showing up Obama Is Probably Not One of Them. https://www.washingtonpost.com/news/monkeycage/wp/2016/03/21/there-may-be-a-lot-of-reasons-putin-changed-russiassyria-policy-but-showingup-obama-is-probably-not-one-of-them/

Hund, W. D., \& Mills, C. W. (2016). Comparing Black People to Monkeys Has Long, Dark Simian History. Huffington Post. http://www.huffingtonpost.com/the-conversation-africa/comparing-black-people-to b 9345322.html

Hussein, B. (1985). Frantz Fanon and the Psychology of Oppression. New York: Plenum Press.

Klikushin, M. (2016). Russian Media Explodes with Vulgar and Racist Anti-Obama Rhetoric. “Obama Schmoe”, Monkey Comparisons and "chimney Sweep" Used to Disparage American President. http://observer.com/2015/12/vulgar-and-racist-anti-obama-rhetoric-inundates-russian-pop-culture/

Lange, C. (2015). The Oprah Effect is in Full Swing with Weight Watchers Earnings. 24/7 Wallst. http://247wallst.com/services/2015/11/06/the-oprah-effect-is-in-full-swing-with-weight-watchersearnings/

Legal Information Institute Encyclopedia (2015). Freedom of Expression Is to Be Protected from Government Interference in America. https://www.law.cornell.edu/wex/first_amendment

Lindorff, D. (2015). Is Obama the Worst President Ever? Counter Punch (Tells the Facts, Names the Names). http://www.infowars.com/75-times-obama-broke-law-during-presidency/ http://www.counterpunch.org/2015/09/03/is-obama- the-worst- president-ever/

Lynne, E. F. (2008). Encyclopedia of Women and American Politics (pp. 385-386). New York: InfoBase Publishing.

Nahon, K., \& Hemsley, J. (2013). Going Viral (p. 137). Polity Press.

New Hope for Women (NHFW) (2016). Abuser Tricks. http://www.newhopeforwomen.org/abuser-tricks 
Nielsen (Media and Entertainment) Company (2015). The Oprah Effect, Closing the Book on Oprah's Book Club. The Nielsen Company.

http://www.nielsen.com/us/en/insights/news/2011/the-oprahhttp://www.nielsen.com/us/en/insights/news/2011/the-oprah-e ffect-closing-the-book-on-oprahs-book-club.htmleffect-closing-the-book-on-oprahs-book-club.html

Office of Public Affairs (Boston College) (2012). Condoleezza Rice to Deliver Commencement Address. Boston: The Trustees of Boston College. http://www.bc.edu/bc_org/rvp/pubaf/06/rice.html

Rabinovitz, J. (2016). Discrimination against Blacks Linked to Dehumanization, Study Finds. Stanford: Stanford University News Service. https://news.stanford.edu/pr/2008/pr-eber-021308.html

Raymond, S. (2016a). Consciousness (Vol. 1, pp. 20-25). Academia Integretia Justicia: Scientific Advancement.

Raymond, S. (2016b). Trauma Based Mind Coding (Vol. 1, pp. 37-40). Academia Integretia Justicia: Scientific Advancement.

Reuters USA (2015). First Lady Promotes Freedom of Speech in China. Reuters Asia Pacific.

http://www.japantimes.co.jp/news/2014/03/22/asia-pacific/u-s-first-lady-promotes-freedom-ofspeech-in-china/\#.Vn81dV KjfIV

Shapiro, B. (2014). The People vs. Barack Obama: The Criminal Case against the Obama Administration. Threshold Divisions. (English)

Shin, L. (2016). The Slippery Slope into Financial Abuse. Forbes. http://www.forbes.com/sites/laurashin/2015/03/19/ill-takecare-of-the-bills-the-slippery-slope-intofinancial-abuse/\#490534 d761b8

Spiering, C. (2015) Actress Jessica Alba Asks Voters to Pledge Allegiance to Obama. Washington Examiner. http://www.washingtonexaminer.com/actress-jessica-alba-asks-voters-to-pledge-allegiance-to-obama/article/2508539

Stanford University (Hoover Institution SUHI) (2015). Condoleezza Rice. Stanford University. http://www.hoover.org/profiles/condoleezza-rice

Stanford University (The Europe Centre STEC) (2015). Condoleezza Rice. Stanford University. http://tec.fsi.stanford.edu/people/condoleezza_rice

Szeming, S. (1941-1945). World War II Memoirs (p. 42). Pittsburgh: University of Pittsburgh.

The Political Insider (2015). Barack Obama Caught in Crime "of the Century". http://www.thepoliticalinsider.com/hugenews-barack-obama-caught-in-crime-of-the-century/

TIME (WORLD) (2016). Michelle Obama Defends Free Internet in China Speech. TIME Inc. http://time.com/34314/michelle-obama-defends-free-internet-inchinaspeech/

Tracinski, R. (2015). Barack Obama: Worst President Ever. The Federalist. http://thefederalist.com/2015/11/19/barack-obama- worst-president- ever/

University of Virginia (UOV) (2015). Barack Obama: Life before the Presidency. Miller Center. http://millercenter.org/president/biography/obama-life-before-the-presidency

Waismel-Manor, I., \& Stroud, N. J. (2012). The Influence of President Obama's, Middle Name on Middle Eastern and US Perceptions. Berlin: Springer Science \& Business Media, LCC.

Wright, C. (2015). Barack Obama Has Done Zero for Black People. The Telegraph. http://www.telegraph.co.uk/news/worldnews/barackobama/11779946/Barack-Obamahasdonezero-for-black-people.html 


\section{Biographical Notes}

The author (researcher) of the current report, Dr Simon Raymond MPH, is a consultant (specialising in medical and scientific research) and an Alumni of Melbourne University (Rank of Number 1 in Australia and Number 33 in the World). The above stated researcher is also qualified as a statistical analyst (qualitative and quantitative), has acted as a reviewer for the respected Medical Journal of Australia, has received invitations internationally to review from prestigious medical journals including JAMA (Journal of American Medical Association) Network, received award in recognition of his research by Royal Australasian College of Surgeons (PCS, 2006) and invited to conferences internationally as an official delegate and researcher. Dr Simon Raymond has acted as the principle researcher in the highest powered form of medical trial-Randomised Controlled Trial (RCT). The above stated researcher is also a member of the Golden Key International Society for honoured and outstanding academics and has been cited as a notable global leader. Prior to his entering of the above professional pursuits, the above stated researcher was Dux of a Catholic College (Secondary College, VCE 2001). Dr Simon Raymond does not consider himself Catholic or Christian (or, identify as any particular religion) but expresses interest in spiritual and consciousness related academia.

\section{Submit or recommend next manuscript to SCIRP and we will provide best service for you:}

Accepting pre-submission inquiries through Email, Facebook, LinkedIn, Twitter, etc. A wide selection of journals (inclusive of 9 subjects, more than 200 journals)

Providing 24-hour high-quality service

User-friendly online submission system

Fair and swift peer-review system

Efficient typesetting and proofreading procedure

Display of the result of downloads and visits, as well as the number of cited articles

Maximum dissemination of your research work

Submit your manuscript at: http://papersubmission.scirp.org/ 